\title{
DIE SOGENAAMDE MODERNE OPVATTING VAN SEKSUALITEIT EN DIE IMPLIKASIES DAARVAN VIR DIE OPVOEDING
}

\author{
G.J.J. Louw \\ Departement Fundamentele Pedagogiek \\ UNISA \\ PRETORIA
}

\begin{abstract}
The sexualisation of modern society and the corresponding massive sex-offensive necessitate fundamental reflection on the so-called modem view of sexuality. In order to reveal some of the fundamental causes for this view of sexuality, characteristics of contemporary Westem societies such as the following are referred to: feelings of discontent, uncertainty, futurelessness and hedonism, the influence of mass media and the discreditation and rejection of marriage as an institution. It appears that sexuality has become even more problematic/complicated in culturally diverse societies since the espousal of a so-called value pluralism has opened the way for all types of sexual malpractices to be regarded as acceptable. Consequently it is demanded that the sexal education which children receive should consist of factual and neutral information on all sexual (mal-)practices. Christian parents/teachers who want to fulfil their calling however, may not shirk their responsibility of providing emphatic guidance to the children entrusted to them according to the Christian view of life and sexality.
\end{abstract}

\section{INLEIDENDE ORIëNTERING}

Dit wil voorkom asof Esterhuyse (1980:3) gelyk het wanneer hy beweer dat die mens se seksualiteit in die huidige tydsgewrig in "... vele opsigte en op verskillende vlakke uitermate problematies geword het". Die probleem sentreer hoofsaaklik daarom dat seks in so 'n mate die hooftema van die menslike bestaan geword het dat daar inderdaad van 'n verseksualiseerde samelewing gepraat kan word. Hierdie verseksualisering van die lewe het ook gepaard gegaan met ingrypende veranderinge in die mens se seksuele gedrag waarna in die gewone omgang soms verwys word met uitdrukkings soos 'seksuele losbandigheid' en 'seksuele permissiwiteit'. Die titel van hierdie artikel en die voorafgaande opmerkings wil egter hoegenaamd nie te kenne gee dat seksuele losbandigheid/permissiwiteit 'n totaal nuwe verskynsel is nie; inteendeel, dit wil voorkom asof dit 'n verskynsel is wat deur al die eeue heen in ' $n$ mindere of meerdere mate waargeneem is. Dit skyn egter of die verskynsel veral in die afgelope twee of drie dekades soveel momentum opgebou het dat dit wêreldwyd en veral in Westerse beskawings 'n hoogbloei bereik het. Huntemann (1964:14) verwys reeds daarna dat die mens, en veral die jeugdige, in die verseksualiseerde samelewing aan 'n massale en 
aggressiewe seks-offensief blootgestel word. In die lig daarvan kan met reg gevra word: het seksuele losbandigheid/permissiwiteit nie reeds die tradisionele waardes en norme op die gebied van die seksuele moraal vervang nie, en is hierdie sogenaamde moderne opvatting van seksualiteit nie reeds die heersende seksuele 'norm' nie? Teen hierdie agtergrond sal gepoog word om aan die hand van enkele wesenstrekke van die kontemporêre samelewing deur te dring na grondliggende oorsake vir die veranderde en veranderende opvatting van seksualiteit. Daarna sal enkele implikasies daarvan vir die opvoeding in oënskou geneem word. Aangesien dit wil voorkom of die sogenaamde moderne opvatting van seksualiteit ten diepste 'n aantasting van die huwelik en die gesin is, sal dié sake besondere aandag in die bespreking ontvang.

\section{DIE KONTEMPORéRE SAMELEWING EN DIE SOGENAAMDE 'MODERNE' OPVATTING VAN SEKSUALITEIT}

Ten aanvang moet beklemtoon word dat seksualiteit tot die wesenlike van die mens behoort en daarom intiem verweef is met die individu se ganse bestaan én met die voortbestaan van 'n gemeenskap/samelewing. Vandaar dat ruim 60 jaar gelede al verklaar kon word: "Sex and reproduction, though only part of life, have a meaning for the whole of it" (Ballance, 1932:10). Om derhalwe 'n behoorlike greep op seksualiteit te verkry, moet die verskynsel nie in isolasie bestudeer word nie. Dit impliseer dat deeglik kennis geneem sal moet word van die omstandighede, die situasie waarin die mens hom in die moderne kontemporêre samelewing bevind. 'n Grondige analise van die moderne samelewing kan egter nie binne die bestek van hierdie bespreking onderneem word nie. Derhalwe sal op kursoriese wyse gekonsentreer word op enkele aspekte daarvan wat besondere segwaarde vir die onderhawige onderwerp het.

\section{$2.1 \quad$ Onvergenoegdheid en onvoldaanheid}

Hoofsaaklik vanweë die skitterende prestasies van die tegnologie as toegepaste natuurwetenskap, kan na-oorlogse Westerse samelewings feitlik deur die bank as massawelvaartsamelewings beskryf word. Die prestasies van die wetenskap en tegnologie/tegniek, het ook die verwagting laat ontstaan dat die wetenskap en tegniek in staat is om alle probleme op te los en 'n utopiese bestaan te verseker. Na aanleiding daarvan het 'n techno-fix-gesindheid begin posvat. Spoedig egter het die ontnugtering gevolg en het gevoelens van onvergenoegdheid en onvoldaanheid ontstaan, omdat die mens al hoe meer daarvan bewus word dat die wetenskap en tegnologie nie almagtig is nie. In die aangesig van voortbestaanskrisisse waarvoor die mens te staan kom, soos Vigs wat besig is om verwoestende afmetings aan te neem, is dit asof die sukses wat die mediese wetenskap gehad het, vervaag en die mens net maar bewus is van die 
onvermoë van die wetenskap om oplossings vir sy eksistensiële nood te bied. Na die mate wat dít tot hom deurdring, hou die toekoms vir die mens wat sy broosheid en eindigheid des te feller beleef, ' $n$ al hoe groter bedreiging in.

\subsection{Onsekerheid en wanhoop aan die toekoms}

In aansluiting hierby moet ook herinner word aan die gevoel van onsekerheid wat gaandeweg in die moderne hoogsgeïndustrialiseerde samelewing ontstaan het - onder andere as gevolg van die hoë mate van outomatisasie en spesialisasie. Dié onsekerheid het reeds sulke afmetings aangeneem dat die mens begin glo het dat hy nie langer in staat is om sy eie behoeftes/nood en hunkeringe te bepaal nie, maar dat sogenaamde 'kenners' dit namens hom moet doen. Juis daardeur word gevoelens van ongeborgenheid vererger omdat die mens se ware behoeftes en hunkeringe nie vervul word nie. Lasch (1980:25) laat hom hieroor soos volg uit: "... we allow experts to define our needs for us and then wonder why those needs never seem to be satisfied". Die rol wat massamedia, soos die koerant en die beeldradio speel om onsekerheid, twyfel en verwarring te skep en te laat voortduur, noodsaak enkele opmerkings oor dié aangeleentheid. In die verband moet daarmee rekening gehou word dat die massamedia 'n magdom inligting uiters vlugtig en fragmentaries vanuit die mees uiteenlopende standpunte aanbied. Dit dra daartoe by dat die mens nie 'n behoorlike greep op die wêreld kan kry nie, omdat hy nie in staat is om die inligting te verwerk en in 'n samehangende lewensbeskouing te orden nie. Met verwysing na televisieprogramme stel Verrelst (1982:82) dit onomwonde: "... de programma's zijn gemaakt vanuit de meest uiteenlopende religieuze of filosofische visies - als er al een visie aan ten grondslag ligt". In 'n sekere sin weet die mens dus veel meer, omdat hy omtrent iets van alles weet. Omdat hy egter weinig/niks daarvan verstaan nie, bied dit hom geen sekerheid nie. In die lig hiervan word tereg gewaarsku dat die televisie daartoe kan lei dat die mens in 'n identiteitskrisis kan beland en totaal uit pas met die wêreld kan raak, sodat selfs die grondslae van die mens se eksistensie, sy wêreldbeskouing en sy belewing van ruimte en tyd gevaar loop om vernietig te word (Verrelst, 1982:97).

Uit die voorafgaande skemer reeds deur dat die onsekerheid wat in die moderne samelewing heers, te herlei is na die talle ingrypende veranderings wat teen 'n ontstellende tempo plaasvind. Hoe radikaal die veranderinge is, blyk daaruit dat daar weinig/geen kontinuïteit tussen verlede, hede en toekoms in die vooruitsig gestel word nie. Daaroor is daar onder andere by Allain (1979:8) geen twyfel nie, soos duidelik blyk uit die volgende opmerking: "While earlier generations prepared their children to live in a world similar to the adult's world, today we don't know the kind of world in which our children will live". Ten einde die verlangde verandering te bevorder, word dit beklemtoon dat verandering nie net meer 'modern' is nie, maar ook noodsaaklik is om 
die mens in staat te stel om meer 'menslik te word en sodoende 'n 'regverdiger' en 'n 'mensliker' samelewing daar te stel. Om dié rede word bereidwilligheid tot verandering as 'n morele bate voorgehou, terwyl onwilligheid tot, en verset teen verandering, as immoreel en onmenslik veroordeel word. Dit is onvermydelik dat die klimaat/gesindheid wat in die samelewing ontstaan het ook op die gebied van die seksuele moraal tot radikale veranderinge sou lei. In 'n wêreld waar alles gedurig verander en niks skynbaar blywende waarde het nie word dit wat anders, obskuur, obseen en mensonterend is, immers juis meer geredelik aanvaar (cf. Damast, 1985:111).

Met inagneming van die voorafgaande is dit te verstane waarom die mens in die moderne geïndustrialiseerde samelewing geen grootse verwagtinge van die toekoms koester nie en waarom beweer word dat die mens so siek is van die moderne samelewing dat hy dreig om in 'n pessimistiese letargie te versink (Verrelst, 1982:24). Aan die wortel hiervan lê 'n ondergangstemming of 'n volslae wanhoop aan die toekoms wat van die moderne mens in Westerse samelewings besit geneem het. Dit het die afgelope dekade of wat so 'n toename in die voorkoms van depressiwiteit tot gevolg gehad dat toonaangewende psigiaters depressiwiteit al beskou as die siekte van die moderne tyd, waaraan na raming reeds in $19875 \%$ van die wêreldbevolking gely het (Faust, 1987:13). As gevolg van die wanhoop aan die toekoms het daar algaande 'n onwilligheid en ' $n$ vrees by die mens ontstaan om op persoonlike en nie-saaklike vlak langtermynverbintenisse met ander aan te gaan. In die Duitse literatuur word na dié verskynsel verwys met die term Bindungsangst (Wingen, 1987:13).

\subsection{Hedonisme en die aanslag op die huwelik}

In reaksie teen die toekomspessimisme wat dreig om die mens se ganse bestaan te oorspoel, het 'n hedonistiese gesindheid ontwikkel. In ooreenstemming met die hedonistiese tydsgees van die welvaartsamelewing, is seksualiteit gereduseer tot seksuele genot en seksuele lus wat onmiddellik bevredig moet word. Huntemann (1964:18) vestig die aandag pertinent daarop dat "... de seksuele lust hebzucht wordt, omdat deze zich in ons verabsoluteert, dus de laatste en hoogste waarde wil zijn waaraan wij blind kunnen vervallen". Die klem wat in die welvaartsamelewing op verbruik/konsumpsie geplaas word, het 'n weggooi-kultuur laat ontstaan wat ook sy stempel afgedruk het op bykans alles wat met die mens se seksualiteit in verband gebring kan word. Dit het tot gevolg gehad dat daar 'n filosofie ontwikkel het waarin die sin en die wese van die seksuele gesoek word in die loutere fisiese en kortstondige genot van die oomblik. Ook die huwelik is trouens reeds in so 'n mate gesubjektiveer dat die vervulling van seksueel-erotiese begeertes doel op sigself geword het (Beinert, 1988:51). Die negatiewe uitwerking wat dit het, ook op bevolkingsaanwas, is daaraan te wyte dat nie die verwek van 'n nageslag nie, maar die bevrediging van seksueel- 
erotiese drifte die botoon voer waar oordrewe klem op seksuele genot geplaas word (Wingen, 1987:16). Die uitlewing van die sex is fun-filosofie is onder andere deur ontwikkelinge op die gebied van die mediese wetenskap moontlik gemaak (cf. Esterhuyse, 1980:33). Hier word byvoorbeeld gedink aan die daarstelling van 'n wye verskeidenheid van voorbehoedmiddels.

Uiteraard het die Bindungsangst waarna vroeër verwys is, ook ernstige implikasies vir die huwelik en die gesin. Tradisioneel vereis die huwelik immers van 'n egpaar 'n bereidwilligheid tot 'n lewenslange, wedersydse verbintenis en toegewydheid, terwyl die behoorlike opvoeding van hul kind(ers) eweneens 'n bykans lewenslange toegewydheid van 'n ouerpaar verg. In die gees van die sogenaamde moderne opvatting van seksualiteit word die Bindungsangst verder gevoed deur die koorsagtigheid waarmee die huwelik en gesinslewe afgetakel word. Dit kom onder andere duidelik na vore waar mense en veral jeugdiges aangemoedig word om seksueel te verkeer met wie hulle wil, waar, wanneer en soos hulle wil. Dit is duidelik dat die oogmerk daarmee is om die samelewing sogenaamd te bevry van begrippe soos homoseksualisme, kuisheid en promiskuïteit.

In ooreenstemming hiermee word die huwelik voorgestel as niks meer nie as maar net nog een van die talle verbintenisse tussen mense, waardeur 'n negatiewe gesindheid teenoor die huwelik bevorder word. Daarby is die gedagte ook verkondig dat die liefde nie langer die huwelik nodig het nie. In sy werk met die veelseggende titel Braucht Liebe (noch) die Ehe? vestig Beinert (1988:90) die aandag daarop dat daar inderdaad tussen 1950 en 1986 'n afname van bykans $40 \%$ in die aantal huwelike gesluit per 1000 inwoners in die Bondsrepubliek van Duitsland (BRD) was, terwyl Wingen (1987:22) melding maak van 'n afname van meer as $25 \%$ net in die loop van die sewentigerjare. Volgens Heigert (1989:6) tree tans net sowat een derde van alle 20-29-jariges in die BRD in die huwelik. Daarteenoor het die aantal ongetroude pare wat saamwoon, tussen 1970-1980 in feitlik elke Westerse land viervoudig vermeerder (Beinert, 1988:74). Wat egskeidings betref, was daar eweneens die afgelope twee dekades ' $n$ dramatiese toename in feitlik alle Westerse samelewings, insluitende die RSA. In die BRD byvoorbeeld, loop tans een uit elke drie huwelike op 'n egskeiding uit (Beinert, 1988:80). In dié verband moet ook kennis geneem word van die verwronge, onmenslike en permissiewe beeld van die liefde, die huwelik en seksualiteit wat deur die massamedia uitgedra word. Die liefde word byvoorbeeld voorgestel as 'n hewige passie waarin man en vrou so totaal in mekaar opgaan dat alle godsdienstige, morele en sedelike beginsels opgeskort mag word. Daarom word daar nie meer owerspel gepleeg nie, maar word ewe vroom bed toe gegaan asof dit die vanselfsprekende gevolg is wanneer ongetroudes tot mekaar aangetrokke voel. Na buite-egtelike kinders word vergoelikend verwys as 'liefdeskinders', terwyl 'n buite-egtelike verhouding as 'n opwindende 'affaire' of 'n seksuele avontuur voorgehou word. Vrouens word uitge- 
beeld as ewig jonk en beeldskoon, en allerlei voorstellings van sogenaamde ideale wyses van geslagsgemeenskap word gemaak. Namate egliede begin agterkom dat die werklikheid nie strook met die geïdealiseerde voorstelling van die massamedia nie tree ontgogeling in. Verrelst (1982:66) is dan ook oortuig daarvan dat juis as gevolg van hierdie onvervulde verwagtinge "... steeds meer paren steeds vlugger uit mekaar gaan".

Wat egter steeds in gedagte gehou moet word, is dat die gangbare opvatting oor seksualiteit ' $n$ wesenlike uitwerking op die strukturering en ordening van 'n samelewing het. Waar absolute/bandelose vryheid op die gebied van die seksuele gepropageer word, moet verwag word dat dié gesindheid na die ganse samelewing en alle terreine daarvan sal deursuur. As sodanig moet rekening gehou word daarmee dat die aanslag op die huwelik en gesin (wat tradisioneel die hoeksteen vorm van Christelik-Westerse samelewings) sentraal staan in die daarstelling van 'n 'nuwe' samelewing.

\subsection{Seksualiteit en kulturele verskeidenheid}

'n Verdere kernaspek van die onderhawige problematiek wat na aanleiding van die voorafgaande na vore kom, is die kwessie van seksualiteit in 'n samelewing wat gekenmerk word deur kulturele diversiteit. Die dilemma waarvoor die mens in hierdie omstandighede te staan gekom het, spreek uit die aandrang op 'n sogenaamde multikulturele benadering ten opsigte van alle fasette van die mens se lewe, insluitende sy seksualiteit. Die heersende tydsgees waaruit sodanige aansprake ontspring, word treffend verwoord in die volgende opmerking: "The popular prefixes of today are hetero, multi and 'poly'; we are somewhat ill at ease with 'mono"' (Pratte, 1979:145).

In aansluiting daarby word respek vir die diversiteit van die moderne sogenaamde demokratiese samelewing en die waardepluralisme wat daarmee saamgaan, bepleit. In die praktyk kom dit daarop neer dat onder andere allerlei afwykende seksuele praktyke as aanvaarbaar/toelaatbaar voorgehou word. Dit word selfs as die plig van die staat beskou om in die gees van ware demokrasie die diversiteit en die geldigheid van die seksuele norme van verskillende groepe te verdra en te beskerm met al die organe waaroor hy beskik (cf. Kluge, 1989:10). Dat so 'n opvatting 'n vrugbare teelaarde skep waarin seksueel-afwykende gedrag kan floreer, benodig geen verdere betoog nie.

Die rede wat aangevoer word waarom alle gedragsvorme/leefwyses aanvaar moet word, is dat moraal 'n sogenaamde 'private' aangeleentheid is. Anders as in die geval van feitelike kennis, word beweer dat daar geen objektiewe maatstaf is waarvolgens bepaal kan word of 'n spesifieke gedragsvorm/leefwyse reg of verkeerd is nie. Om die 
rede mag skole byvoorbeeld ook nie 'n bepaalde opvatting van seksuele moraal aan leerlinge voorhou nie omdat dit kwansuis aanstoot kan gee aan, of verwarring kan veroorsaak by leerlinge behorende tot verskillende etniese/kulturele groepe. Ten einde sogenaamd reg te laat geskied teenoor almal, moet leerlinge ingelig word oor soveel as moontlik seksuele opvattings. In ooreenstemming met hierdie standpunt word dit byvoorbeeld as ' $n$ aantasting beskou van die beginsels waarop ' $n$ ware plurale demokrasie berus indien daar op enige wyse teen losbandige en sedelose onderwysers gediskrimineer sou word, omdat sulke onderwysers dan glo positiewe identifikasiefigure sou wees vir leerlinge wat ook graag sedeloos en losbandig wil lewe en ook 'n alternatiewe leefwyse daarstel vir diegene wat ordentlik wil leef en 'n hoë sedelike standaard wil handhaaf (Klein, 1978:89). Die gevolg is dat leerlinge in openbare skole in die VSA onder die dekmantel van kursusse in gesins- en seksopvoeding uitvoerig bekend gestel word met allerlei seksuele aangeleenthede en seksuele (wan-)praktyke (Steinbacher, 1971: onder andere 28, 34, 38, 48-49, 51).

Veral na die uitbreek van Vigs wat bestempel word as "... a deadly chain-letter for sexually liberated societies" (Almond, 1988:153) word met hernieude ywer daarop aangedring dat leerlinge so volledig moontlik oor selfs die mees walglike sogenaamde seksuele handelinge ingelig moet word. Macklin (1988:145) laat daaroor geen twyfel nie: "But to educate effectively requires a direct and explicit discussion of the very sexual practices which many may find repulsive or at least embarrassing." Die bedreiging wat Vigs inhou, moet volgens Altman (1986:166) benut word om die behoefte aan 'n meer homoseksueelgerigte seksonderrig in skole te beklemtoon. Daar word trouens selfs beweer dat enige seksopvoeding wat nie uitvoerig handel met aangeleenthede soos prostitusie, homoseksualisme, onanie (Almond, 1988:153) gebrekkig/onvoldoende is. Onder die dekmantel van Vigs-bekampingsprogramme word gepleit dat omvattende/volledige seksvoorligting op 'n sogenaamde neutrale en saaklike wyse net die relevante medies-biologiese feite aan leerlinge moet oordra (cf. Bennet, 1988:93). In die meeste gevalle word 'n breedvoerige uiteensetting gegee van sogenaamde "safe sex practices" (Macklin, 1988:145) dit wil sê, van voorbehoedmiddels en die gebruik daarvan om besmetting met die Vigsvirus te vermy (cf. Kluge, 1989:117-120). Derhalwe moet kondome vryelik beskikbaar wees vir enigeen wat dit wil benut. So naarstiglik word die gebruik van die kondoom gepropageer as die enigste effektiewe wyse waarop Vigs voorkom kan word dat inderdaad van 'n kondoom-manie gepraat kan word.

In die lig van die voorafgaande is dit duidelik dat die finale maatstaf wat aangelê word om te bepaal of 'n saak goed/sleg is, nie die algemeen aanvaarde waardes en norme is wat in God en die Christelike godsdiens en die tradisies van 'n bepaalde gemeenskap veranker is nie, maar die mens self. Elkeen moet in die lig van sy besondere situasie en omstandighede en in ooreenstemming met sy eie oordeel/ervaring/behoeftes self 
besluit wat vir hom reg/verkeerd is. Aangesien die buite-menslike oorsprong van norme ontken word en norme as 'n individueel-subjektiewe aangeleentheid beskou word, word norme van hul bindingskrag beroof. Langs hierdie weg moet noodwendig in 'n nihilisme beland word. Wanneer dié stadium bereik is, is reeds ver gevorder op die weg na 'n sogenaamde globale gemeenskap/eenheidstaat waarin die ideaal van die eenheid van die mensdom na bewering bereik sal word.

Pienaar (1988:8) vestig egter die aandag daarop dat die globalisme of holisme nie net na eenheid streef nie, maar ook na eendersheid en eenvormigheid en dat alle teenstellings soos goed en kwaad, sedelik en onsedelik, oorlog en vrede, sondig en heilsaam volgens so 'n siening opgehef moet word om die ideaal te verwesenlik. Oor die aandeel wat die onderwys/opvoeding daaraan het om 'n globale perspektief en 'n globalistiese verwysingsraamwerk te vestig, laat Hoopes (1980:6) geen twyfel nie. Die gevolgtrekking waartoe geraak kan word met inagneming van wat tot dusver aangevoer is, is dat die omverwerping van die bestaande orde en die vestiging van 'n globalistiese bestel grondliggend is aan die sogenaamde moderne opvatting van seksualiteit en die daaruitspruitende hedendaagse seksopvoeding in openbare skole in die VSA. Verwysende na hierdie soort permissiewe en walglike seks-'opvoeding' verklaar Steinbacher (1971:iii) uitćruklik: "Sex instruction is only one small part of a massive bull-dozer operation to convert America's public school system into a series of behavioral science clinics for reshaping and restructuring the children into the International Child of Orwell's 1984". As sodanig moet daarmee rekening gehou word dat die bestaande orde juis as gebrekkig, ongeneeslik, sterwend voorgestel word ten einde die totstandkoming van 'n nuwe orde, die sogenaamde 'global society' te vergemaklik, en dat die uitbuiting en manipulasie van die mens se seksualiteit 'n sleutelrol daarin speel.

Teen die agtergrond van die voorafgaande kan nou meer spesifiek aandag gegee word aan die implikasies wat die sogenaamde moderne opvatting van seksualiteit vir die opvoeding het.

\section{ENKELE IMPLIKASIES VIR DIE OPVOEDING}

Wanneer oor die implikasies van die sogenaamde moderne opvatting van seksualiteit vir die opvoeding besin word, kan die toegewyde Christen nie anders as om 'n Christelik-gefundeerde standpunt daaroor in te neem nie. In sy opvoedingsbemoeienis met jeugdiges moet die Christen-opvoeder se optrede en sy gesindheid daarvan getuig dat hy die kind as 'n gawe van God respekteer wat tot die hoogste Waarheid gelei moet word, sodat dit hom in staat stel om tot eer van God te lewe. Aangesien die mens egter van nature geneig is tot die sonde, is dit die opvoeder se verantwoordelikheid om die kind te beskerm teen bose invloede wat sou kon verhinder dat hy die mens word 
wat God bedoel het hy moet wees. Kragtens die doopbelofte is elke Christen-ouer (en daarmee ook die onderwyser wat in die skool die plek van die ouer inneem) immers daartoe verbind om die kind in God se weë te onderrig/laat onderrig en dit by die kind in te skerp dat hy Verbondskind is.

Ten aanvang moet dit ook duidelik gestel word dat dieselfde beginsels wat vir opvoeding oor die algemeen geld, ook ten grondslag behoort te lê van enige besinning oor die implikasies van die sogenaamde moderne opvatting van seksualiteit vir die opvoeding. Streng gesproke behoort daar dus liefs nie 'n onderskeid gemaak te word tussen opvoeding en geslags-/seksopvoeding nie. Opvoeding is immers opvoeding en in en deur die opvoeding moet die jeugdige so begelei word dat hy as verantwoordelike volwassene 'n betekenisvolle en menswaardige bestaan sal kan voer. Uiteraard sluit dit ook die mens se seksualiteit in omdat dit 'n integrale deel van menslike eksistensie is. Trouens, die ware en dieperliggende betekenis van seksualiteit kom eers dan na vore as dit beskou word teen die agtergrond van die mens se totale menswees. Bennett (1988:19) verwys daarna dat "... sex is inextricably connected to the psyche, to the soul ... to personality at its deepest levels ... It involves men and women in all their complexity".

\subsection{Seksualiteit nie net'n medies-biologiese aangeleentheid nie}

Die voorafgaande impliseer dat seksualiteit veel meer as 'n medies-biologiese aangeleentheid is en daarom mag in die opvoeding ook nie slegs met die oordrag van suiwer feitelike medies-biologiese kennis aangaande die werking van kliere en hormone volstaan word nie. Waar dit gebeur, word die menslike waardigheid aangetas en die mens gedegradeer tot die vlak van 'n dier wat deur sy instinkte en drifte beheer word. Anders as die dier moet die mens sy drifte/drange beheer en op 'n menswaardige wyse uiting gee daaraan.

Die skerp toename in onder andere tienerswangerskappe en aborsies onder tieners lewer afdoende bewys daarvan dat ' $n$ medies-biologiese benadering nie tot die beheersing van seksuele drifte lei of daarin slaag om ongewenste seksuele gedrag te voorkom nie. Ten spyte van omvattende medies-biologiese seksuele voorligting in openbare skole in die VSA, moet in dié verband daarvan kennis geneem word dat meer as die helfte van alle Amerikaanse adolessente geslagsgemeenskap het voor hulle 17 is; meer as een miljoen Amerikaanse tieners jaarliks swanger raak en dat meer as die helfte van hulle nog nie 18 is as die baba gebore word nie; meer as 400000 tieners in Amerika jaarliks ' $n$ aborsie het en dat die aantal ongehude moeders tussen 1960 en 1980 met $200 \%$ toegeneem het (Bennett, 1988:92). Daarbenewens is daar talle kinders wat nie feitelike, medies-biologiese seksuele voorligting van volwassenes ontvang het nie, maar 
gesonde, normale volwassenes geword het en gelukkige huwelike gesluit het. Hoe misplaas die aanspraak is dat seksuele kennis waarborg dat tieners seksueel verantwoordelik sal optree, blyk ook uit die volgende opmerking van Haffner (1989:200): "The majority of teen pregnancies are unintended, even though most teenagers are wellacquainted with the facts about how pregnancies occur". (Eie kursivering.) Dit wil dus voorkom of deeglike en formele seksuele voorligting inderdaad nog geen waarborg is dat jeugdiges wat dié voorligting ontvang het, ordentlike en geestelik gesonde volwassenes sal word en gelukkige huwelike sal sluit nie.

Met inagneming van die voorafgaande ontstaan die vraag of dit nie juis hierdie kennis is wat jeugdiges se nuuskierigheid aanwakker en aanleiding gee tot seksuele eksperimentering en afwykende seksuele gedrag nie, terwyl nie besef word dat die meeste tieners emosioneel nie opgewasse is vir die implikasies van volwasse seksuele verhoudings nie. Janzing (1987:6) stel dit duidelik dat om te weet wat reg is 'n mens nog nie in staat stel om korrek op te tree nie. Dit is veral van toepassing op daardie gebiede van die mens se lewe wat sterk deur die gevoel/emosie gerig word. Ken moet eers verdiep tot verstaan en insig. Immers: kennis verg innerlike krag en die wil om dit menswaardig te benut en wilsopvoeding setel in die keuse tussen goed en kwaad, reg en verkeerd. Laasgenoemde op sy beurt, word gefundeer in gewetensbeslissings as saak van oortuiging en belydenis.

Dit skyn egter of seksuele inligtingskursusse waaraan jeugdiges onderwerp word in die naam van die sogenaamde moderne opvatting van seksualiteit juis seksuele eksperimentering en afwykende en perverse praktyke wil bevorder. Dit word gedoen deur jong mense bewus te makk van die bestaan van sodanige praktyke en die praktyke voor te hou as sogenaamde aanvaarbare alternatiewe seksuele gedrag. In dié verband word daaraan herinner dat jeugdiges van alle moontlike vorme van seksuele gedrag kennis mót neem, aangesien van die standpunt uitgegaan word dat wat ook al van seksualiteit gesê word, in elk geval vir een of ander persoon aanstoot sal gee (Fay \& Gordon, 1989:213). In talle sogenaamde seksuele opvoedingskursusse word uitsluitlik juis op hierdie sogenaamde alternatiewe seksuele gedragsvorme gekonsentreer (cf. Haffner, 1989:198). Ironies genoeg vorm dié benadering die basis van verreweg die meeste antiVigsprogramme, terwyl daar onomstootlike bewyse is dat Vigs juis deur die sogenaamde alternatiewe seksuele gedrag opgedoen kan word. Om dié rede moet die volgende vermaning met die nodige erns bejeën word: "We must assure that in our haste to implement AIDS education we do not inadvertently damage our children's sexual futures" (Haffner, 1989:202). Gesien in die lig van die feit dat seksualiteit ' $n$ integrale deel van die mens se bestaanswyse is, hou die bogenoemde benadering inderdaad 'n bedreiging vir die voortbestaan van die mensdom in.

Uit wat tot dusver aangevoer is, behoort dit ook duidelik te wees dat die sogenaamde 
moderne opvatting van seksualiteit ook vir die Christendom as sodanig 'n bedreiging inhou en dat veral die Protestantse etiek toenemend in die welvaartsamelewing in die spervuur kom. In 'n groot mate sentreer die probleem rondom seksualiteit in die hedendaagse Westerse samelewing immers om die stryd tussen ongebreidelde menslike drifte en 'n maatskaplike orde gebou op wette, sedelike beginsels en die Christelike godsdiens. Die Christen-opvoeder durf egter nie toelaat dat jeugdiges wat aan sy sorg toevertrou is, as gevolg van hierdie sogenaamde nuwe seksuele moraal deur sielewroeging verteer word nie. Ten einde te voorkom dat die kinderlike ontwikkeling as gevolg hiervan skeef loop of dat die kind die spoor totaal byster raak, behoort die opvoeder uit al die verskillende opvattings van seks/seksualiteit waarmee die mens vanuit alle oorde gekonfronteer word, 'n verantwoordelike keuse te mak en in ooreenstemming daarmee doelgerigte, positiewe begeleiding te verskaf oor wat reg / verkeerd ten opsigte van seksuele aangeleenthede is. Oor die noodsaaklikheid daarvan dat onderwysers 'n waardige voorbeeld moet stel om die kind in staat te stel om betekenis aan sy seksualiteit te gee, laat Bennett (1988:101) geen twyfel nie as hy daarop wys dat onderwysers identifikasiefigure vir leerlinge is. Dit is daarom van die allergrootste belang dat die dade, ideale en oortuigings van onderwysers wat verantwoordelik is vir seksuele opvoeding hoegenaamd geen twyfel sal laat oor die Christelike aard daarvan nie. Die volwassene moet steeds onthou dat hy meer opvoed deur wat hy doen as deur wat hy sê en meer deur wat hy is as deur wat hy doen. Die wyse waarop man en vrou daagliks met mekaar in die huwelik omgaan, is derhalwe vir die kind se (seksuele) opvoeding veel belangriker as enige formele seksuele voorligting wat gegee mag word, omdat dit die grondslag van sy seksuele opvoeding lê. Hier word onder andere gedink aan sake soos die bereidwilligheid van beide egliede om hulle aan mekaar te verbind en hul wedersydse toegeneentheid en liefde, maar ook aan die wyse waarop hulle mekaar help/bystaan, vir mekaar instaan, oorleg met mekaar pleeg, mekaar respekteer en saam dinge doen en geniet. Met verwysing hierna merk DresenCoenders (1962:21) tereg op: "Als het kind zijn ouders als elkaars 'wederhelft' kan beleven, is een voorname grondslag voor zijn sexuele opvoeding gelegd." Vir die Christen-opvoeder sal Christelike norme die grondslag van sodanige bemoeienis vorm. Deurdat die jeugdige gehelp word om met behulp van 'n Christelike maatstaf seksuele kennis te interpreteer en seksuele gedrag te beoordeel, word hy in staat gestel om die ware betekenis van seksualiteit te kan verstaan en sy eie seksualiteit met die nodige agting te bejeën. Die opvoeder se bemoeienis met die kind mag derhalwe geen twyfel daaroor laat dat seksualiteit by uitstek 'n morele aangeleentheid is nie, soos ook duidelik gestel word in die volgende opmerking: "Moral issues cannot be divorced from sexuality education. In fact, these issues form the foundation of sexuality education programs" (Fay \& Gordon, 1989:211). Daarom kan hoegenaamd nie akkoord gegaan word met die opvatting dat kennis van die wyses waarop Vigs oorgedra word en van sogenaamde veilige seks, die enigste effektiewe wyse is waarop die siekte voorkom kan word en die enigste hoop op 'n meer rasionele en menslike antwoord op 
die probleem is nie (cf. Macklin, 1988:145). In ooreenstemming hiermee word veral die gebruik van kondome aanbeveel, soos reeds vroeër terloops opgemerk is. Deur die gebruik van kondome te propageer, word aan jeugdiges gesuggereer dat buitehuwelikse seks aanvaarbaar is, dat ouers/volwassenes genoeë daarmee neem dat kinders seksueel aktief is en inderdaad verwag dat jeugdiges geslagsgemeenskap sal/moet hê. Die kommer oor dié toedrag van sake word ook gedeel deur Mieth (1987:5) wat daarop wys dat die vraag na die morele verantwoording van seksuele gedrag nie beantwoord word bloot deur dit makliker vir jeugdiges te maak om kondome te bekom en deur inligting oor die gebruik van kondome te verskaf nie. Deur die gebruik van voorbehoedmiddels aan te beveel en dit so vryelik beskikbaar te stel, word 'n ernstige morele dwaling begaan. Die enigste werklike remedie teen die verspreiding van Vigs is 'n hernieude morele bewussyn wat neerslag vind in 'n diepe respek vir menslike seksualiteit, trou in die huwelik en die verwerping van geslagsverkeer buite huweliksverband.

\subsection{Seksualiteit en sosiale verandering}

Ook en veral in die sogenaamde plurale demokratiese samelewing waar fundamenteel verskillende waardes en norme oor liggaamlikheid en seksualiteit gehuldig word, is dit absoluut noodsaaklik dat die opvoeder ondubbelsinnig standpunt moet inneem in verband met seksuele vraagstukke, omdat die kind uiteindelik sy plek as volwassene moet volstaan in ' $n$ bepaalde gemeenskap waarin partikuliere waardes en norme geld. Reeds in 1968 het Oldendorff (1968:69) kategories verklaar dat alle biologiesgefundeerde behoeftes van die mens, insluitende en veral seksuele behoeftes, maatskaplik-kultureel genormeer en gekanaliseer word. Waar kulturele en lewensbeskoulike verskille op die gebied van die seksuele geïgnoreer/misken word, word die gelykmaking van die mensdom in die moderne industriële samelewing ook op die gebied voltrek en word te kenne gegee dat alle vorme van seksuele gedrag aanvaarbaar/toelaatbaar is, soos reeds vroeër opgemerk is. Hierdie gelykmaking het reeds gelei tot 'n toename in die aantal huwelike tussen mense met verskillende nasionaliteite en kulture. Volgens Strätling (1988:479) besef elke gesaghebbende huweliksraadgewer dat juis hierdie verskille dikwels daarvoor verantwoordelik is dat sulke huwelike misluk. Dit is egter nie so bekend onder die publiek nie, omdat huweliksberaders nie graag melding daarvan maak nie, uit vrees dat verwysings daarna as diskriminasie vertolk kan word. As sodanig gaan dit dus in die sogenaamde nuwe opvatting van seksualiteit om die manipulering en uitbuiting van die menslike seksualiteit in belang van sosiale verandering en nie om begrip van die kind se bestaansnood en begeleiding tot sinvolle lewensontvouing nie (cf. Oberholzer, 1989:527-528). Pogings om 'n sogenaamde 'neutraliteit', hetsy aktief of passief (Dodde, 1990:23), op seksuele gebied te handhaaf, lei by die jeugdige nie net tot intense verwarring en ongeborgenheid nie, 
maar bevorder inderdaad seksuele losbandigheid en seksuele eksperimentering, soos reeds vroeër opgemerk is. Deur die sogenaamde neutrale (seksuele) opvoeding word immers juis toestande geskep waarin (seksuele) revolusie kan gedy, aangesien dit by uitstek die onverbonde mens is wat hom tot revolusionêre gedrag wend in 'n poging om sin aan sy lewe te gee (cf. Lasch, 1980:33). Dit is daarom die taak van die Christenopvoeder om toe te sien dat daar by die jeugdige hoegenaamd geen onsekerheid sal wees oor wat normaal en toelaatbaar ten aansien van die seksuele is nie. In sy opvoedende bemoeienis met die jeugdige moet die Christen-onderwyser steeds in gedagte hou dat hy teenoor God rekenskap sal moet doen oor sy (bege-)leiding aan daardie kinders wat aan sy sorg toevertrou is.

\subsection{Seksualiteit en huweliksgeluk}

In aansluiting hierby moet ook gewys word op die onhoudbaarheid van die aanspraak dat seks net daar is vir die genot daarvan. Seksualiteit, of erger nog, slegs een aspek daarvan soos seksuele genot, mag nie gelykgestel word aan menswees of menslike geluk as sodanig nie, omdat die bevrediging van seksuele drange uitsluitlik ter wille van die genot van die oomblik, geen blywende geluk waarborg nie. Trouens, dit lei dikwels tot ontgogeling en 'n gevoel van onvoldaanheid/leegheid wat steeds weer seksuele konsumpsie vereis, sodat die mens heen en weer geslinger word tussen begeerte en walging. Van die seksuele as liefdesdaad tussen egliede is daar in so 'n onmiddellike genotsbevrediging geen sprake nie. Daarteenoor kan geslagsverkeer binne 'n monogame huwelik 'n belangrike bydrae tot huweliksgeluk lewer. Dit is daaraan toe te skryf dat die huwelik in sy suiwer vorm op onselfsugtige liefde gebou is en 'n duursame verbintenis in die vooruitsig stel waarvan onder andere wedersydse en heelhartige trou en lojaliteit en volkome toegewydheid aan mekaar die grondslag vorm. Vandaar dat verklaar word "... geen coïtus zonder coëxistentie" (Huntemann, 1964:37). Waar die huwelik dus gesluit word met die bedoeling om die ander te misbruik vir die konsumpsie van seks, mis die huwelik sy doel en word seks vergoddelik. Aangesien 'n huwelik nie net in die seksuele veranker is nie, bly die huwelik, ten spyte van versteurde seksuele relasies, 'n huwelik (cf. Huntemann, 1964:100).

\section{MORAAL - GEEN 'PRIVATE' AANGELEENTHEID}

Ook die aanspraak dat moraal 'n 'private' aangeleentheid is, verdien enkele opmerkings, veral as gelet word op die implikasies wat dit op bevolkingsaanwas het. In dié verband moet kennis geneem word van die kwynende kinderbevolkings in moderne geïndustrialiseerde samelewings, onder andere omdat talle egpare hul besluit om min/geen kinders te hê regverdig met die argument dat dit geheel en al 'n private aan-

Koers 56(3) 1991:447-461 
geleentheid is. So 'n besluit is egter nie net 'n persoonlike saak nie, omdat wat 'n mens doen en is altyd ook 'n uitwerking het op ander en in die besonder op die gemeenskap en die volk waartoe jy behoort. As sodanig het elke mens ook'n verantwoordelikheid ten opsigte van die lot van toekomstige geslagte wat nie ontduik kan word nie. Wingen (1987:29) vind dit nodig om in dié verband te waarsku dat wat vir die onmiddellike toekoms vir 'n bepaalde egpaar/gesin in hulle besondere omstandighede goed mag voorkom, op die lange duur katastrofaal vir'n gemeenskap en dus ook vir die individue waaruit dit saamgestel is, mag wees. Waar moraliteit tot 'n private aangeleentheid verklaat word, word in elk geval nie verdraagsaamheid nie, maar veel eerder morele verval bevorder. Dat moraal altyd ten diepste gemoeid is met die mens se gerigtheid op iets wat buite homself lê, kom duidelik na vore as Ortega Y. Gasset (1962:235) verklaar: "... moraal is steeds naar wezen geweest het gevoel van onderdanigheid aan iets, het bewustzijn van te moeten dienen en van verplichtingen te hebben". Liefde is immers nie bloot 'n emosie nie, maar 'n gesindheid wat gestalte moet vind in 'n bereidwilligheid om te dien en op te offer. Dit impliseer dat die mens ook ' $n$ verpligting het ten aansien van die voortplanting van die ras/volk waartoe hy behoort en dat ook dié aspek as een van die primêre funksies van die huwelik beklemtoon sal word. Tradisioneel is die huwelik immers gedefinieer as 'n wettige verbintenis tussen twee persone van teenoorgestelde geslag met die uitsluitlike doel om mekaar in liefde by te staan en kinders in die lewe te bring (cf. Beinert, 1988:68). Wie moraal as'n sogenaamde private aangeleentheid beskou en die lewe/huwelik in ooreenstemming daarmee sien as iets waaruit die individu ten alle koste maksimale genot moet put, moet daarop bedag wees dat so 'n huwelik sal misluk. Wie daarteenoor die lewe sien as diens en toewyding aan ander, bou sy huwelik op 'n stewige fondament.

\section{SAMEVATTING}

Uit die voorafgaande blyk duidelik dat die verseksualisering van die samelewing ten nouste saamhang met die aanslag op Christelike waardes en norme. Na die mate wat daarin geslaag word om 'n normverskuiwing weg van 'n Christelike lewensbeskouing te bewerkstellig, word die lewe vir talle mense in die gesekulariseerde en individualistiese samelewing toenemend sinloos. Die mens kan egter net sin beleef as hy deur middel van doelgerigte Christelike begeleiding te midde van die tydelikheid/kortstondigheid van sy aardse bestaan die bo-tydelike sin daarvan ontdek. Ten einde die kind in staat te stel om tot sinvolle wêreldbewoning te kom, moet hy dus ingedra en ingelyf word in 'n bepaalde kultuurwèreld, aangesien die mens se hunkeringe en behoeftes in die nouste verband staan met die kulturele gemeenskap en die kollektiewe lewensbeskouing wat daarin gehuldig word. Juis om diê rede is dit in die hedendaagse samelewing meer as ooit noodsaaklik dat Christelike opvoeding voltrek sal word in 'n Christelike en lewensbeskoulik-homogene klimaat om te voorkom dat die sogenaamde mondige mens in die afgrond stort. 


\section{BIBLIOGRAFIE}

ALLAIN, VA. 1979. Futuristics and education. Bloomington: Phi Delta Kappa

ALMOND, B. 1988. AIDS and international ethics. Ethics and Intemational Affairs, 2:139-153.

ALTMAN, D. 1986. Aids in the mind of America. New York : Anchor Press.

BALLANCE, E.R. 1932. Sex in human life. Oxford: The Alden Press.

BEINERT, W. red. 1988. Braucht Liebe (noch) die Ehe? Regensburg : Verlag Friedrich Pustet.

BENNETT, W.J. 1988. Our children and our country. New York : Simon \& Schuster.

DAMAST, W. 1985. Die meervoudigheid en veelvormigheid van enkele cictydse ideologiese tendense met verwysing na moontlike pedagogiese implikasies. Pretoria. (Ongepubliseerde proefskrif (D.Ed.) - Universiteit van Suid-Afrika.)

DODDE, N.L. 1990. Het verschil tussen openbaar en bijzonder is allecn nog bestuurlijk van aard. Secularisering en onderwijs. Vemieuwing. Tijdschrift voor ondenwijs en opvoeding, 49(1):21-24.

DRESEN-COENDERS, H.M. 1962. De voorlichting in de opvoeding. Hilversum/Antwerpen : Paul Brand.

ESTERHUYSE, W.P. 1980. Die mens en sy seksuele moraal. Durban/Pretoria : Butterworth

FAY, J. \& GORDON, S. 1989. Moral sexuality education and democratic values. Theory into Practice, 28(3):211-216.

FAUST, V. 1987. Depressionsfibel. Stuttgart : Gustav Fischer Verlag.

HAFFNER, D.W. 1989. AIDS and sexuality education. Theory into Practice, 28(3):198-202.

HEIGERT, H. 1989. Angst vor dem Abenteuer Leben. Vom Wohl und Wehe der Kinder in unserer Gesellschaft. Stimme der Familie, 36(6):5-7.

HOOPES, D.S. 1980. Intercultural education. Bloomington : Phi Delta Kappa.

HUNTEMANN, G.H. 1964. Seksualiteit in het moderne leven en wat de Bijbel ervan zegt. Wageningen : Zomer en Keunings.

JANZING, A. 1987. AIDS - eine neue sexualpädagogische Herausfordcrung. Jugend und Gesellschaft, 4:5-7.

KLEIN, J.T. 1978. A pluralistic model for educational policy making. Educational Theory, 28(2):85-89.

KLUGE, N. 1989. Die Liebe auf der Spur. Düsseldorf : Albanus Verlag.

LASCH, C. 1980. The culture of narcissism. American life in an age of diminishing expectations. Londen : Albacus.

MACKLIN, E.D. 1988. AIDS: implications for families. Family Relations, 37 (2):141-148.

MIETH, D. 1987. AIDS - die ethische Exponiertheit der Probleme. AJS Infornationen, 4:4-7.

OBERHOLZER, M.O. 1989. Outentieke opvoeding in 'n multikulturele en tegnologies-georiënteerde tydsgewrig. Suid-Afrikaanse Tydskrif vir Opvoedkunde, 9(3):521-530.

OLDENDORFF, A. 1968. Lichamelijkheid, seksualiteit en cultuur. Hilversum : Paul Brand.

ORTEGA, Y., GASSET, J. 1962. De opstand der horden (12e druk). 's-Gravenhage : H.P. Leopolds.

PIENAAR, J.J. 1988. Die temporaliteitspedagogick. 'n Waarheid- en sinsoekende begronding. Pretoria Universiteit van Suid-Afrika.

PRATTE, R. 1979. Pluralism in education. Conflict, clarity and commitment. Springfield : Charles C. Thomas.

STEINBACHER, J, 1971. The child seducers. Educator Publications.

STRäTLING, B. 1988. Ehe und Familie in unserer Gesellschaft. Jugendwohl. Zeitschrift für Kinder- und Jugendhilfe, 69(11):475-482.

VERRELST, W. 1982. De cultuur van het onbehagen. Antwerpen/Amsterdam : De Nederlandsche Boekhandel.

WINGEN, M. 1987. Kinder in der Industricgesellschaft - wozu? Analysen, Perspektiven, Kurskorrekturen. Osnabrück : Fromm. 
